\title{
Assessing the Influence of Demographic Factors on Community Participation in a Demand Driven Development Project: The Case of Hazina Ya Maendeleo Ya Pwani Approach in Coastal Kenya
}

\author{
Farida A. Hassan ${ }^{*}$, Hilda A. Ong'ayo ${ }^{1}$, Melckzedeck K. Osore ${ }^{2}$ \\ ${ }^{1}$ Pwani University, Kilifi, Kenya \\ ${ }^{2}$ Kenya Marine and Fisheries Research Institute, Mombasa, Kenya \\ Email: *naahiyah@gmail.com
}

How to cite this paper: Hassan, F.A., Ong'ayo, H.A. and Osore, M.K. (2019) Assessing the Influence of Demographic Factors on Community Participation in a Demand Driven Development Project: The Case of Hazina Ya Maendeleo Ya Pwani Approach in Coastal Kenya. Open Journal of Social Sciences, 7, 209-224.

https://doi.org/10.4236/jss.2019.71018

Received: December 4, 2018

Accepted: January 19, 2019

Published: January 22, 2019

Copyright $\odot 2019$ by author(s) and Scientific Research Publishing Inc. This work is licensed under the Creative Commons Attribution International License (CC BY 4.0).

http://creativecommons.org/licenses/by/4.0/

\begin{abstract}
While recognizing that community participation stimulates local self-reliance and reduced dependency on outside agencies, it is also appreciated that a number of factors influence participation. This study was conducted to determine the demographic factors that influence community participation by using empirical data collected from a sample of 326 community members who participated in the implementation of the Hazina Ya Maendeleo Ya Pwani (HMP) project. The research was carried out at the Kenya coastal region comprising six counties namely, Mombasa, Taita Taveta, Kwale, Kilifi, Lamu and Tana River. Data was collected using a semi-structured questionnaire. Using a multinomial logistic regression, the study examined the extent to which demographic factors comprising age, gender, type of economic activity and level of education influenced community participation in development initiatives. Study findings revealed that gender and level of education were the two demographic factors that significantly influenced community participation, with women showing greater participation. The study also revealed that demographic factors comprising age and type of economic activity had no significant influence on community participation. The study concludes that in order to stimulate optimal community participation in development initiatives at the grass-root level, it is worthwhile to make gender and educational level considerations. The study recommends that there is a need to enhance the participation of men in development interventions considering the many socially constructed roles already assumed by women.
\end{abstract}




\section{Keywords}

Community Participation, Demand Driven Development, Hazina Ya Maendeleo Ya Pwani, Demographic Factors, Kenya Coastal Counties

\section{Introduction}

Community participation is a widely used concept and its definition does not always neatly fit into a single discipline. In the health sector, it is defined as a process whereby people, both individually and in groups, exercise their right to play an active and direct role in the development and delivery of appropriate health services [1]. Agricultural economists describe it as a process of farmers getting benefits, while political scientists focus on votes and decision-making [2]. In community development, it is understood as a route of social progress in which people meet their collective needs [3]. The common understanding is that community participation entails involving communities in assessing their own needs and in developing strategies to meet them, thus increasing intervention ownership and sustainability [4]. This perspective is shared by Sheikh et al. [5] who define community participation as a systematic involvement of significant number of people, in diverse activities to manage their own problems while carrying the concept of togetherness. In the context of this study, however, the term participation is operationalized as engaging communities in identifying their challenges, prioritizing their needs and taking responsibility for implementation and management of development projects with a view to address some of their most immediate needs [6].

In developing countries, participatory methods have been successful in attaining high levels of participation and collaboration in development projects, stimulating communities to self-mobilize and take independent action [7]. The rationale has been to fully engage communities for them to take initiatives and actions are stimulated by their own thinking and deliberations for effective control of their development agenda. Community participation is therefore the means through which local self-reliance is stimulated, thus reducing dependency on the outside agencies [8]. Authors in a wide range of literature emphasize on the importance of community participation in planning, implementation, monitoring and evaluation of development initiatives [9]. Participation of local people in development processes allows the community to have control over the resources, boost involvement and decision-making in developing their common comfort [5]. It is considered fundamental to the ownership and success of development initiatives [10] and essential in bringing about sustainable community development at the grassroots level [11]. It is believed that involving communities in assessing their own needs and in developing strategies to meet those needs can increase intervention ownership and sustainability [12]. Omosa [13] underscored the need to involve local people when designing projects since de- 
velopment cannot be defined from outside and be imported for implementation.

As a key paradigm for rural development in Kenya, community participation in development initiatives has been firmly anchored in the constitution. The Kenya Constitution provides a strong legal framework for citizen participation in development processes. Article 1 of the constitution states that all sovereign power is vested in the people of Kenya and the exercise of this power occurs at the national and county levels either directly through citizen participation or indirectly through democratically elected representatives [14]. Article 10(2)(a) states that "participation of the people" is one of the country's values and principles of governance while Article 232(1)(d) instructs public servants to include citizens "in the process of policy making”. Equally, the Kenya's' Vision 2030-the national long-term development blueprint, targets to invest in the people of Kenya in order to improve the quality of life for all Kenyans [15]. Guided by these legal frameworks, reforms in sectors such as education, health, security, environment, entrepreneurship, water, sports among others have provided platforms for people participation in development projects with the objective of improving overall service delivery. In Kenya today, many governmental organizations have increasingly been involved in supporting community projects aimed at improving livelihoods of the community in which they operate [16].

Participation of the community is mostly done through structures such as Community Based Organizations (CBOs) specifically formed for the purposes of achieving common good projects [1] and is now among the fastest growing mechanism for channeling development assistance [17]. In many instances therefore, these have served as instruments for consultation with supposed beneficiaries about planning and implementation of community projects [10]. For this reason, the development landscape is today littered with committees formed in the wake of these changes, mandated as "user groups" to take on some of the functions of provisioning, regulation and management that previously resided with the state [18]. Consequently, communities especially in rural areas have been engaged in development initiatives for both collective and individual benefit. Findings from the 2006 National Council of Community Based Organizations (NCCBO) survey showed that there were a total of 26027 registered CBOs in Kenya [15] which have increasingly become the key target group for implementing development projects at the grass root level [16]. CBOs positively affect the process of rural change as they contribute to better income, improvement in health and literacy status of the local populations. $\mathrm{CBOs}$ serve as a link between citizens and the government and are often thought to be more responsive to community concerns than government agencies or private businesses [19].

In addition to the available evidence on the benefits of participation, it is also important to understand factors that influence community participation in development projects. In literature various authors agree that demographic and socio-economic factors have to a large extent an influence on community participation. For instance, Bauma et al. [20] argue that the level of participation in social and civic community life is significantly influenced by individual so- 
cio-economic status and other demographic characteristics. Supporting this line of thought, Plummer [21] describes factors such as skills and knowledge, employment, cultural beliefs, gender, education and literacy social and political marginalization to be key in affecting community participation. In his study conducted in Africa and Latin America, Awortwi [22] concluded that income levels and housing categories have positive relationships with factor influencing community participation and supervision. Dorsner [23] argues that factors such as social norms, administrative rules and procedure, the legal system and income distribution impede community participation [23].

In this context therefore, this study sought to determine demographic factors that influence community participation by exploring the perspectives and experiences of coastal communities who participated in the implementation of projects supported through a community grant facility translated in Kiswahili language as Hazina Ya Maendeleo Ya Pwani (HMP). The HMP project was conceptualized under the auspices of the Kenya Coastal Development Project (KCDP) financed by the World Bank [24]. The main objective of HMP was to improve access to social services among communities-a key challenge for the coastal residents [15]. Government agencies and development partners have implemented many projects and programs in the region that targeted to address the challenge of access to social services. Among the many projects implemented at the Kenya coast is HMP that adopted a Community Driven Development (CDD) approach to engage coastal communities in improving access to social services [25]. Through the CDD approach coastal communities through registered $\mathrm{CBOs}$ were engaged in the identification, development and implementation of priority projects that address the challenge of access to social services. Through its emphasis on participation and focus on community empowerment strengthened through development of technical and financial capacity, the CDD provided a unique way to respond to developmental challenges associated with limited access to social services. The aim of this study is therefore to examine the extent to which demographic factors such as age, gender, level of education and type of economic activity influenced community participation in the HMP project.

\section{Methodology}

\section{Study area}

The study was carried out in coastal Kenya that comprises six counties namely: Mombasa, TaitaTaveta, Kwale, Kilifi, Lamu and Tana River (Figure 1). The climate of the region varies with distance from the coast and it becomes drier towards the inland from the ocean and from south to north [26]. Covering an area of approximately $83,000 \mathrm{~km}^{2}$, the coast region has a population of approximately 3.3 million people with a birth rate of 3\% [27]. About $69.7 \%$ percent of the coastal population lives below the poverty line, with some areas such as Ganze in Kilifi scoring an alarming 84\% making it the second poorest region of 


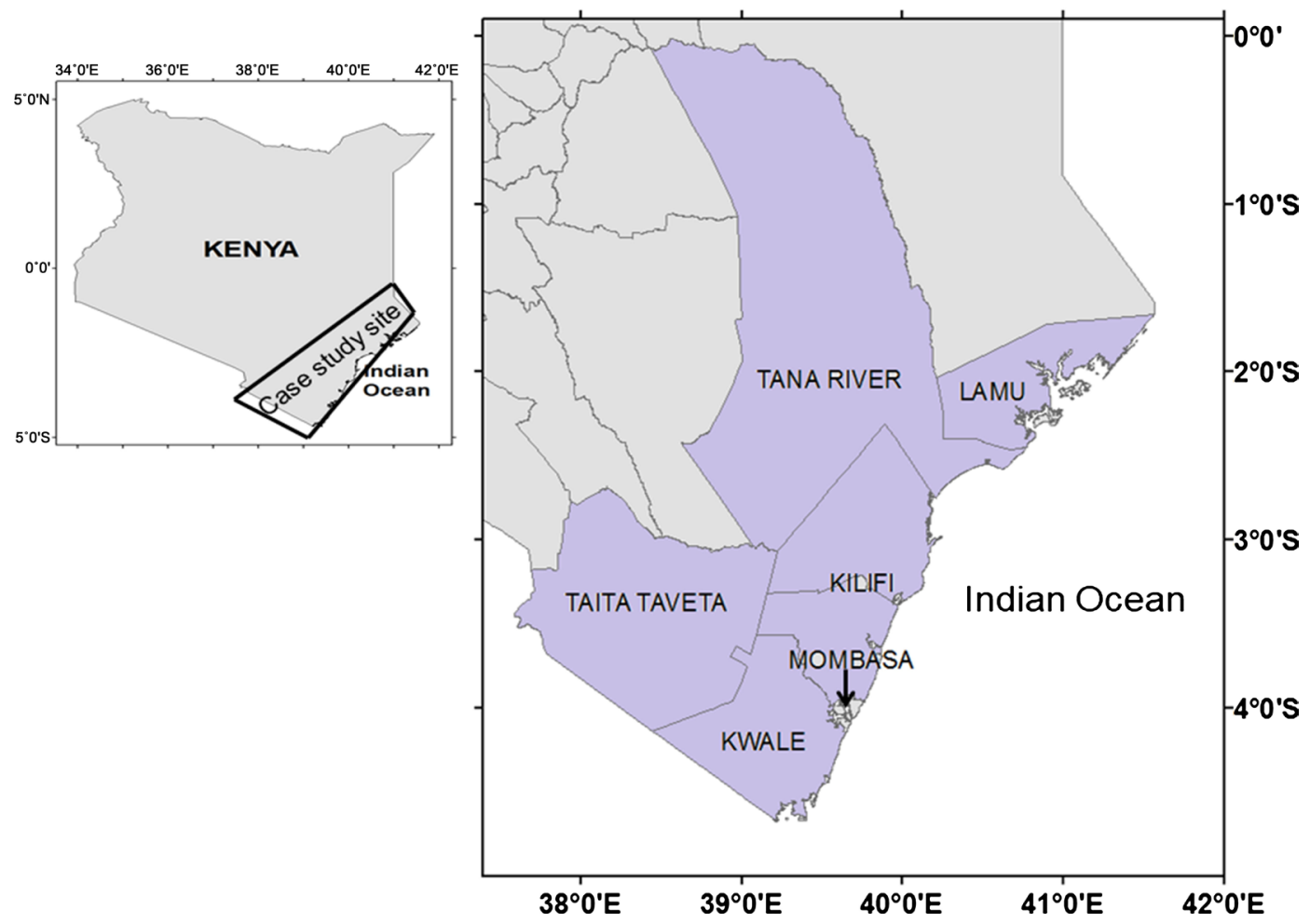

Figure 1. Map of coast region of Kenya, covering the six coastal counties. Source: Hassan et al., 2017.

Kenya's eight regions after North Eastern with 73.9\% [15]. The region is endowed with unique ecosystems with rich natural resources including marine fish, coral reefs, sea-grass beds, mangrove forest and a diverse cultural heritage that underpin the livelihood of the coastal communities. The Kenya coast also hosts a large migrant population of different ethnic and racial origins [15]. The continued migration into the coastal region that introduces more competition for the natural resources that underpin coastal livelihood only serves to exacerbate the already high poverty levels.

\section{Study Population and Sample Size}

The target study population comprises the communities living in coastal region currently estimated at 3.3 million people [27]. The accessible population is the 2160 community members drawn from the CBOs that participated in the implementation of the HMP project and are also the beneficiaries of the same [25]. A sample size of 326 persons was computed using Ross et al. [28] equation. Proportionate sampling technique was used to get a fair representation of the study sample from the six coastal counties. Simple random sampling techniques were used to obtain the study respondents using a sampling frame obtained from HMP records [29].

\section{Data Collection and Analysis}

Data from respondents was collected using a semi-structured questionnaire that was pre-tested in communities that were not ultimately included in the study, and later revised. The questions solicited responses regarding the extent of community participation structured in a three-point comprising $1=$ Commu- 
nity not consulted on project activities; $2=$ Community was consulted on project activities; 3 = Community actively engaged on project activities. Demographic information such as age, gender, level of education and economic activity of respondents was also collected to provide respondent's on their views regarding the influence of demographic factors on community participation in the HMP project. A total of 285 community members were taken through a one to one interview session using the questionnaire. The accuracy of information provided in questionnaires was verified through cross checking with verbal interview transcripts and observations notes made during field trips for the purpose of improving internal and external validity of the research. The collected data was processed and analyzed using the Statistical Package for Social Sciences Version 20.0. Descriptive statistics such as frequency and percentage were used to present the data. A multinomial logistic regression was used to determine the influence of demographic factors on community participation. The choice of the statistical tool was informed by the fact that the assumptions for fitting a linear regression were violated. In addition, because the outcome variable (community participation) were measured in three categories namely; $1=$ active participation, 2 = consulted and $3=$ not consulted. As such a multinomial regression was found fit. In this model the reference category was "those not consulted".

\section{Results}

Demographic data of the respondents are shown in Table 1.

Majority $(53 \% ; n=151)$ of the respondents fell within the age group of $31-50$ years, whereas an additional $40 \%(\mathrm{n}=111)$ were above 50 years of age and only 3 respondents were below 20 years (Table 1$)$. More than half $(56 \%, n=161)$ of the respondents were females, while $46 \%(n=133)$ were males. In terms of household sizes, 42.8\% $(n=122)$ of the respondents had small households of 1 5 persons while $41.4 \%(n=118)$ had household size of $6-10$ persons. Very few respondents $(7.4 \%, \mathrm{n}=214)$ had household sizes of $11-15$ persons. The educational attainments of majority $(33.7 \%, n=96)$ of the respondents was at Primary level while those illiterate were $31.2 \%(\mathrm{n}=89)$. Only $7.7 \%(\mathrm{n}=22)$ and $2.8 \%(\mathrm{n}$ $=8)$ had college and university education. Majority $(64 \%(n=183)$ of the respondents engaged in farming as their main source of livelihood with very few $(0.7 \%, \mathrm{n}=2)$ engaging in fishing. Given the fact that the region is endowed with marine and specifically fishery resources this finding is of great concern. Versleijen and Hoorweg [30] confirm that challenges such as reduced catches, more competition from fellow artisanal fishermen as well as foreign fishermen, tourism and human settlement have made many fishermen to resort to other income-generating activities. $18.9 \%$ of the respondents engaged in small business with a few engaged in gainful employment (8.1\%) and the remaining (8.1\%) serving as housewives or undertaking casual jobs such as masonry.

\section{Community Participation by Demographic Factors}

Using a multinomial logistic regression, the study assessed the influence of 
Table 1. Demographic characteristics of respondents.

\begin{tabular}{|c|c|c|}
\hline Variables & Frequency (n) & Percent (\%) \\
\hline \multicolumn{3}{|l|}{ Age } \\
\hline$<20$ Years & 3 & 0 \\
\hline 20 - 30 Years & 20 & 7 \\
\hline $31-50$ Years & 151 & 53 \\
\hline$>50$ Years & 111 & 40 \\
\hline \multicolumn{3}{|l|}{ Gender } \\
\hline Male & 124 & 44 \\
\hline Female & 161 & 56 \\
\hline \multicolumn{3}{|l|}{ Household size } \\
\hline 1 - 5 Persons & 122 & 42.8 \\
\hline $6-10$ Persons & 118 & 41.4 \\
\hline $11-15$ Persons & 24 & 8.4 \\
\hline 16 Persons and above & 21 & 7.4 \\
\hline \multicolumn{3}{|l|}{ Level of education } \\
\hline Primary school & 96 & 33.7 \\
\hline High School & 70 & 24.6 \\
\hline College & 22 & 7.7 \\
\hline University & 8 & 2.8 \\
\hline Illiterate & 89 & 31.2 \\
\hline \multicolumn{3}{|l|}{ Occupation } \\
\hline Farming & 183 & 64.2 \\
\hline Fishing & 02 & 0.7 \\
\hline Trading & 54 & 18.9 \\
\hline Formal employment & 23 & 8.1 \\
\hline Others & 23 & 8.1 \\
\hline
\end{tabular}

Field survey data collected in January 2017.

demographic factors comprising gender, age, level of education, and type of economic activity on community participation in development initiatives (Table 2). In this multinomial regression model the reference category was "those not consulted". The table below shows the output from the multinomial model and the odds ratios (Exp (B)) were converted to probabilities.

\section{Gender Perspective}

The results show that from a gender perspective, there was a statistically significant difference $(p<0.05)$ between females and males in terms of participation in development initiatives where women were more likely (94.2\%) to participate in development activities compared to men. There was a $94 \%$ relative probability that females who were consulted would participate in community 
Table 2. Community participation by demographic factors.

\begin{tabular}{|c|c|c|c|c|c|c|c|c|c|}
\hline \multirow{2}{*}{ Participate } & \multirow{2}{*}{ B } & \multirow{2}{*}{ Std. Error } & \multirow{2}{*}{ Wald } & \multirow{2}{*}{$\mathrm{df}$} & \multirow{2}{*}{ Sig } & \multirow{2}{*}{$\operatorname{Exp}(B)$} & \multirow{2}{*}{ Probability } & \multicolumn{2}{|c|}{ 95\% Confidence Interval for $\operatorname{Exp}(B)$} \\
\hline & & & & & & & & Lower Bound & Upper Bound \\
\hline \multicolumn{10}{|l|}{ Consult } \\
\hline Intercept & -2.924 & 1.949 & 2.251 & 1 & 0.134 & & & & \\
\hline$[$ Gender $=1]$ & 2.788 & 0.792 & 12.381 & 1 & 0.000 & 16.252 & 94.2 & 3.439 & 76.807 \\
\hline$[$ Gender $=2]$ & $0^{\mathrm{b}}$ & . & . & 0 & . & . & 0 & . & . \\
\hline$[$ Age $=1]$ & -2.995 & 0.000 & . & 1 & . & .050 & 4.76 & 0.050 & 0.050 \\
\hline$[$ Age $=2]$ & -0.913 & 1.493 & 0.374 & 1 & 0.541 & .401 & 28.62 & 0.021 & 7.488 \\
\hline$[$ Age $=3]$ & 0.240 & 0.808 & 0.088 & 1 & 0.766 & 1.272 & 55.99 & 0.261 & 6.200 \\
\hline$[$ Age $=4]$ & $0^{\mathrm{b}}$ & . & . & 0 & . & . & & . & . \\
\hline$[$ Educ $=1]$ & 1.315 & 0.940 & 1.959 & 1 & 0.162 & 3.725 & 78.84 & 0.591 & 23.500 \\
\hline$[$ Educ $=2]$ & 0.949 & 1.169 & 0.659 & 1 & 0.417 & 2.582 & 72.08 & 0.261 & 25.516 \\
\hline$[$ Educ $=3]$ & -0.223 & 1.605 & 0.019 & 1 & 0.890 & .800 & 44.44 & 0.034 & 18.600 \\
\hline$[$ Educ $=4]$ & 1.542 & 3.666 & 0.177 & 1 & 0.674 & 4.672 & 82.37 & 0.004 & 6165.130 \\
\hline$[$ Educ $=5]$ & $0^{\mathrm{b}}$ & . & . & 0 & . & . & & . & . \\
\hline$[$ Econ $=1]$ & 2.049 & 1.514 & 1.832 & 1 & 0.176 & 7.758 & 88.58 & 0.399 & 150.709 \\
\hline$[$ Econ $=2]$ & 2.587 & 9.215 & 0.079 & 1 & 0.779 & 13.294 & 93.00 & $1.906 \mathrm{E}-007$ & $927,174,299.534$ \\
\hline$[$ Econ $=3]$ & 2.943 & 1.770 & 2.765 & 1 & 0.096 & 18.966 & 94.99 & 0.591 & 608.564 \\
\hline$[$ Econ $=4]$ & 3.014 & 1.856 & 2.636 & 1 & 0.104 & 20.363 & 95.32 & 0.536 & 774.348 \\
\hline$[$ Econ $=5]$ & $0^{\mathrm{b}}$ & . & . & 0 & . & . & & . & . \\
\hline \multicolumn{10}{|l|}{ Active } \\
\hline Intercept & -0.582 & 1.461 & 0.159 & 1 & 0.690 & & & & \\
\hline$[$ Gender $=1]$ & 2.166 & 0.709 & 9.337 & 1 & 0.002 & 8.726 & 89.72 & 2.174 & 35.016 \\
\hline$[$ Gender $=2]$ & $0^{\mathrm{b}}$ & . & . & 0 & . & . & & . & . \\
\hline$[$ Age $=1]$ & 18.383 & 0.000 & . & 1 & . & $96,264,271.645$ & 100 & 96264271.65 & $96,264,271.65$ \\
\hline$[$ Age $=2]$ & -0.401 & 1.149 & 0.122 & 1 & 0.727 & 0.670 & 40.12 & 0.070 & 6.368 \\
\hline$[$ Age $=3]$ & 0.184 & 0.715 & 0.067 & 1 & 0.796 & 1.202 & 54.59 & 0.296 & 4.881 \\
\hline$[$ Age $=4]$ & $0^{\mathrm{b}}$ & . & . & 0 & . & . & & . & . \\
\hline$[$ Educ $=1]$ & 2.199 & 0.851 & 6.681 & 1 & 0.010 & 9.019 & 90.02 & 1.702 & 47.799 \\
\hline$[$ Educ $=2]$ & 2.303 & 1.023 & 5.062 & 1 & 0.024 & 10.000 & 90.91 & 1.345 & 74.327 \\
\hline$[$ Educ $=3]$ & 1.897 & 1.242 & 2.334 & 1 & 0.127 & 6.666 & 86.96 & 0.585 & 75.981 \\
\hline$[$ Educ $=4]$ & 3.307 & 3.498 & 0.894 & 1 & 0.344 & 27.305 & 96.47 & 0.029 & $25,912.610$ \\
\hline$[$ Educ $=5]$ & $0^{\mathrm{b}}$ & . & . & 0 & . & . & & . & . \\
\hline$[$ Econ $=1]$ & 1.563 & 1.018 & 2.355 & 1 & 0.125 & 4.772 & 82.67 & 0.648 & 35.119 \\
\hline$[$ Econ $=2]$ & 2.868 & 8.112 & 0.125 & 1 & 0.724 & 17.609 & 94.63 & $2.193 \mathrm{E}-006$ & $141,407,455.593$ \\
\hline$[$ Econ $=3]$ & 1.695 & 1.357 & 1.560 & 1 & 0.212 & 5.449 & 84.49 & 0.381 & 77.934 \\
\hline$[$ Econ $=4]$ & 0.503 & 1.376 & 0.133 & 1 & 0.715 & 1.653 & 62.31 & 0.111 & 24.535 \\
\hline$[$ Econ $=5]$ & $0^{\mathrm{b}}$ & . & . & 0 & . & . & & . & . \\
\hline
\end{tabular}

a. The reference category is: Not Consulted. $b$. This parameter is set to zero because it is redundant. 
development initiatives compared to those not consulted. The results also showed the $89.72 \%$ probability that females who were actively engaged in the process will participate in development activities compared to those not consulted. The implication of these findings is that compared to men, women are more likely to participate in development activities when consulted and actively engaged.

\section{Age}

From the present study, the result in Table 2 shows that there was no significant difference $(p \geq 0.05)$ between the different age categories in terms of participation in development initiatives.

\section{Level of Education}

When comparing those consulted and those not consulted, there was no significant difference $(p>0.05)$ between the various educational levels in terms of community participation in development initiatives Compared to subjects in the other levels of education, those with college level education had a lower probability (44.44\%) of participating in development activities when consulted compared to those not consulted. This could mean that individuals in this category have craft skills that enable them to engage in other income generating activities and may not find time to participate in community development initiatives compared to those with university education who find it hard to get gainful employment. However, when comparing the actively engaged and those not consulted, there was a statistically significant difference ( $p$ $<0.05$ ) between individuals with Primary and High School levels of educational compared to subjects who are illiterate or those with college and university education. When actively engaged, individuals who are educated have a probability of between $86.96 \%$ - to $96.47 \%$ to participate in development activities compared to those who are educated but not consulted. This therefore means that level of education is a determinant of community participation in development projects.

\section{Type of Economic Activity}

The results (Table 2 ) show that there was no statistically significant difference $(p>0.05)$ among individuals in participation in development initiatives. There was however, a probability of between $88.58 \%-95.32 \%$ for individuals in the different economic activity categories to participate in development initiatives when consulted compared to those not consulted. There was also, a probability of between $62.31 \%-94.93 \%$ for the subjects in all economic categories to participate when actively engaged compared to those not consulted. This therefore means that when communities are consulted or actively engaged they will participate in development activities regardless of their current economic engagement. It is important to note that the type of economic activity undertaken by an individual or household influences to a great extent the income level and as such it may imply that the income level was not a factor determining community participation. 


\section{Discussion}

\section{Gender Perspective}

The findings concur with those of Mensah [31] in their study of the relationship between socio-demographic characteristics and community participation using the Chi-square test $\left(x^{2}\right)$ of goodness-of-fit. From the study [31], the gender variable was found to be significantly related to community participation. However, unlike in the current study, men tended to show greater participation in development activities than their female counterparts. Similar results were reported by Safari et al. [32] where the gender variable was found to be a determinant of community participation in development activities but in this specific case more men compared to women, were involved in tourism-related activities. The study findings are also similar to those of Jaafar et al. [33] who reported that gender had a significant moderating effect on community participation in development activities where men were found to be generally more predisposed to participating in developmental processes than their female counterparts. This is probably because women from more deprived backgrounds often experience low self-confidence, which acts as a barrier to their participation [34]. In addition, majority of the respondents in this study were female who play a large part in family responsibilities thus giving them little time to participate in development initiatives. Similar results were reported by Torgerson and Edwards [35] that while women are more inclined than men to participate in community work, the time-consuming family obligations disproportionately shouldered by women can constrain their participation.

On the contrary, the present study findings are not in line with those of Gabayon [36] who found that there was no significant difference in participation based on gender as both males and females had almost the same participation rate.

\section{Age}

The study findings however, contradict those of Jaafar et al. [37] who reported that age had a significant moderating effect on community participation in development activities. The study findings are also contrary to those of Oladele [37] who claimed that age plays a vital role in community participation. The study results are not in line with the findings by Harill [38] who reported that socio-demographic characteristics such as age influenced residents' attitudes towards community participation in development initiatives in general. The study results are however similar to those of Gabayon [36] who found that age does not define people's participation in local community development issues.

In addition, the results also showed that when actively engaged, there was $100 \%$ probability that individuals below 20 years will participate in development activities compared to the other age categories when not consulted. The implication of this finding is that the high youthful population in the country today, could serve as a demographic dividend especially if they are actively engaged in development activities. Due to their fresh motivation, capabilities, and innova- 
tiveness they can act as a catalyst for achieving development goal. An added benefit here is the possibility of keeping them away from vices such as involvement in crime, drug and substance abuse etc.

\section{Level of Education}

The study results are in line with those of John [39], who asserted that educational level of the citizenry has a significant correlation in the level of public participation. Similarly, Joshi and Houtzager [40], contends that education has a high positive correlation with publics engagement in local governance. Similar results were reported by Mugizi et al. [41] who argued that education is essential in enhancing long-term participation of local community in any development initiatives. The results agree with those reported by Dorsner [23] who argued that the level of education in the community affects the level of community participation in development projects. He asserts that altogether what is needed to ensure equal participation in community development activities is not just educated project leaders but also having a community with adequate level of basic education. Dorsner [23] attest that in Senegal community projects participation of villagers was affected by the low educational level and thereby the low management, organizational and leadership skills available in the community to take part in the project especially at decision making level. The results are also in agreement with those obtained by Speer et al. [42] and Shamiyulla and Ramu [43], who reported that the level of education is a significant variable influencing community participation in development activities. This argument concurs with the thinking of Aworti [22] who argued that participation increases with the education level. In his study, he noted that educated households will anticipate the benefits of community self-help and therefore participate in its development. Similar results were reported by Ganesh and Surendra [44] in their study in Nepal where the participation of farmers in agricultural activities was found to be influenced by the education level and number of trainings, received by the community. Similarly, Joshi and Houtzager [41], contends that education has a high positive correlation with publics participation in local governance.

The present study findings contradict with those of Aworti [22] who asserts that education in itself is not entirely a determining variable in community participation. He asserts that many uneducated households scored even better than those with secondary school education in variables such as: membership of community organization, attendance at meetings and participation in planning while those with good education level speak more in meetings than those without education do. The study findings are contrary to those of Saidu, et al. [45] in a study conducted in Kano state of Nigeria where education was found to add negatively to community participation in decision making process as majority of the educated people look for better job opportunities rather than getting involved in agricultural activities. High education level can also be a hindering factor in community participation as explained by Dorsner [23] in which she indicates that educated members of the communities at times are not available for 
their community even if they have interest as they tend to have other business commitments.

\section{Type of Economic Activity}

The present results contradict those of Awortwi [22] in his studies carried out in Africa and Latin America which concluded that income levels have positive relationships with factor influencing community participation. The results also contradict those of Jansky [46] who asserts that the levels of participation in social and civic community life are significantly influenced by individual socioeconomic status. The study results do not concur with previous studies that have provided evidence to the fact that income influences community participation in tourism [47] [48]. Similar results were reported by Brodie et al. [49] who opined that the socio economic group a person belongs to has an impact on his/her level of participation as people from lower socio economic groups often have less access to resources and practical support making their participation in community development initiatives rather difficult and limited.

In summary therefore majority $(53 \% ; n=151)$ of the respondents fell within the age group of $31-50$ years, with over half $(56 \%, \mathrm{n}=161)$ being females. $42.8 \%(\mathrm{n}=122)$ of the respondents had small households of $1-5$ persons while the educational attainment of majority $(33.7 \%, \mathrm{n}=96)$ of the respondents was at Primary level. Respondents who were illiterate constituted $31.2 \%$ of the respondents. Majority (64\% $(n=183)$ of the respondents engaged in farming with very few $(0.7 \%, \mathrm{n}=2)$ engaging in fishing. Of the demographic factors assessed for their influence on community participation, only gender and level of education were found to be statistically significant $(p \geq 0.05)$. Age and economic activities were found to have no significant influence on community participation.

\section{Conclusions}

From the findings of the study, evidence shows that community participation in development initiatives is related to gender and educational level of the community members. It can be concluded that gender and level of education influence community participation. It is therefore recommended that it is worthwhile to make gender and educational level considerations in order to stimulate optimal community participation in development initiatives. In addition, given the fact that educational level is a predictor of community participation in development initiatives, the study recommends that a lot of effort should be put by Coastal County Governments, Non Governmental Organizations and other key stakeholders in addressing the high illiteracy level among coastal communities. This will not only encourage community participation in development initiatives, but will also permit the achievements of the benefits associated with community involvement in development interventions.

This study has also revealed that youths have a great potential in participating in development activities when actively engaged. As such, given the high youthful population in Kenya, it may be worthwhile to tap on this demographic divi- 
dend to initiate development activities at community level. By this way, the twin objectives of engaging the youth in development projects and keeping them away from vices such as drug and substance abuse will be achieved.

It has emerged from this study that women are more inclined to participate in development initiatives at the community level than their male counterparts. Participation of men in development activities should be enhanced considering the many socially constructed roles already assumed by women which may potentially limit their active participation.

\section{Acknowledgements}

We wish to acknowledge the contributions of Kenya Marine and Fisheries Research Institute (KMFRI) through the Kenya Coast Development Project (KCDP) and its Component of HMP, the National Government and Coastal County Government in terms of allocating resources and staff for this work. KCDP Task Team Leaders from the World Bank Mr. Dinesh Aryal and Ms. Veruschka Schmidt are appreciated for their support. We also wish to sincerely thank all the residents of the coastal region for accepting to participate in this study.

\section{Disclosure}

This work is part of the $\mathrm{PhD}$ Thesis currently undertaken by the corresponding author at Pwani University, Kilifi, Kenya.

\section{Conflicts of Interest}

The authors declare no conflicts of interest regarding the publication of this paper.

\section{References}

[1] Oakley, P. and Kahssay, H. (1999) Community Involvement in Health Development: An Overview. In: Kahssay, H. and Oakley, P., Eds., Community Involvement in Health Development. A Review of the Concept and Practice, WHO, Geneva, 3-19.

[2] Cohen, J. and Uphoff, N. (1977) Rural Development Participation: Concepts and Measures for Project Design, Implementation and Evaluation. Cornel University, Ithaka.

[3] Asnarulkhadi, A.S. and Fariborz, A. (2009) People's Participation in Community Development: A Case Study in a Planned Village Settlement in Malaysia. World Rural Observations, 1, 45-54.

[4] Howard-Grabman, L., Miltenburg, S.A., Marston, C. and Portela, A. (2017) Factors Affecting Effective Community Participation in Maternal and Newborn Health Programme Planning, Implementation and Quality of Care Interventions. BMC Pregnancy and Childbirth, 17, 268. https://doi.org/10.1186/s12884-017-1443-0

[5] Sheikh, J.M., Redzuan, B.M., Samah, A.A. and Ahmad, N. (2014) Factors Influencing Farmers' Participation in Water Management: A Community Development Perspective. IOSR Journal of Humanities and Social Science (IOSR-JHSS), 19, 59-63. 
[6] Hassan, F., Ong'ayo, H., Osore, M., Morara, G. and Aura, C. (2017) Effect of Community Participation in Access to Social Services: A Case Study of Hazina Ya Maendeleo Ya Pwani Approach in Coastal Kenya. Open Journal of Social Sciences, 5, 160-180. https://doi.org/10.4236/jss.2017.511012

[7] Chambers, R. (1992) Rural Appraisal: Rapid, Relaxed and Participatory. Discussion Paper \#311, Institute of Development Studies, Sussex, UK.

[8] Cornwall, A. (2008) Unpacking "Participation": Models, Meanings and Practices. Community Development Journal, 43, 269-283. https://doi.org/10.1093/cdj/bsn010

[9] Duncker, C., Matsebe, N. and Austin, M. (2006) Use and Acceptance of Urine-Diversion Sanitation Systems in South Africa. Water Research Commission, Gezina, ZA.

[10] Hassan, F., Ong'ayo, H. and Osore, M. (2018) Measuring the Level of Community Participation in a Demand Driven Development Project: Case of Hazina Ya Maendeleo Ya Pwani Approach in Coastal Kenya. (Yet to Be Published)

[11] Chambers, R. (2007) Poverty Research: Methodologies, Mindsets and Multidimensionality. IDS Working Paper 293, Institute of Development Studies (IDS), University of Sussex.

[12] Draper, A.K., Hewitt, G. and Rifkin, S. (2010) Chasing the Dragon: Developing Indicators for the Assessment of Community Participation in Health Programmes. Social Science \& Medicine, 71, 1102-1109. https://doi.org/10.1016/j.socscimed.2010.05.016

[13] Omosa, K.E. (2005) The Impact of Water Conflicts on Pastoral Livelihoods; The Case of Wajir District in Kenya. International Institute for Sustainable Development 161 Portage Avenue East, 6th Floo.

[14] Government of Kenya (2010) Constitution of Kenya. Government Printer, Nairobi.

[15] Government of Kenya (2008) Kenya Vision 2030: Ministry of Planning, National Development and Vision 2030.

[16] Sally, M.W. and Rosemary, J. (2017) Effect of Community Participation in the Implementation of Community Based Projects in Kieni Sub-County. International Journal of Project Management, 1, 1-19.

[17] Khwaja, I.A. (2004) Is Increasing Community Participation Always a Good Thing? Journal of the European Economic Association, 2, 427-436. https://doi.org/10.1162/154247604323068113

[18] Cornwall, A. and Gaventa, J. (2001) From Users and Choosers to Makers and Shapers: Repositioning Participation in Social Policy. IDS Working Paper 127, IDS, Brighton.

[19] Mwaura, M. and Ngugi, K. (2014) Factors Affecting Performance of Community Based Organizations Projects in Kisii County, Kenya. International Journal of Social Sciences Management and Entrepreneurship, 1, 51-67.

[20] Bauma, F.E., Robert, A.B., Carolyn, C.M., Charlie, J.M., Eva, M.C., Kathy, M.A. and Robert, C.P. (2000) Epidemiology of Participation: An Australian Community Study. Journal of Epidemiology and Community Health, 54, 414-423. https://doi.org/10.1136/jech.54.6.414

[21] Plummer, J. (2002) Municipalities and Community Participation: A Sourcebook for Capacity Building. Earthscan, London.

[22] Awortwi, N. (2012) The Riddle of Community Development: Factors Influencing Participation and Management in Twenty-Nine African and Latin American Communities. Community Development Journal, 48, 89-104. 
[23] Dorsner, C. (2004) Social Exclusion and Participation in Community Development Projects: Evidence from Senegal. Policy and Administration, 4, 366-382. https://doi.org/10.1111/j.1467-9515.2004.00396.x

[24] Aura, C., Hassan, F., Osore, M.K., Musa, S., Morara, G. and Uku, J. (2015) A Comprehensive Public-Private Partnership Concept for Resources Sustainability from a Mega-Project Management Multi-Level Perspective. International Journal of Management and Sustainability, 4, 218-236. https://doi.org/10.18488/journal.11/2015.4.11/11.11.218.236

[25] Hassan, F.A., Ong'ayo, H.A. and Osore, M.K. (2018) Measuring the Level of Community Participation in a Demand Driven Development Project: Case of Hazina Ya Maendeleo Ya Pwani Approach in Coastal Kenya. Open Journal of Social Sciences, 6, 189-203. https://doi.org/10.4236/jss.2018.612017

[26] Nicholson, C.F., Thornton, P.K., Mohammed, L., Muinga, R.W., Mwamachi, D.M., Elbasha, E.H., Staal, S.J. and Thorpe, W. (1999) Smallholder Dairy Technology in Coastal Kenya. An Adoption and Impact Study. ILRI (International Livestock Research Institute), Nairobi, $68 \mathrm{p}$.

[27] Government of Kenya (2009) Kenya National Census. Government Printer, Nairobi.

[28] Ross, C., Lawrence, C. and Thomas, P. (2002) Air University Sampling and Surveying Handbook: Guidelines for Planning, Organizing, and Conducting Surveys. University Press of the Pacific.

[29] HMP Operational Manual (2015) Kenya Coast Development Project-KCDP.

[30] Versleijen, N. and Hoorweg, J. (2004) From Farming to Fishing: Marine Resource Conservation and a New Generation of Fishermen. Western Indian Ocean Journal of Marine Science, 7, 1-14.

[31] Mensah, I. (2016) Effects of Socio-Demographic Characteristics and Perceived Benefits of Tourism on Community Participation in Tourism in the Mesomagor Area of the Kakum National Park, Ghana. Athens Journal of Tourism, 3, 211-230. https://doi.org/10.30958/ajt.3-3-3

[32] Safari, J., Gowele, V. and Lwelamira, J. (2015) Involvement in Tourism Activities and Perceived Benefits in Communities around Udzungwa Mountain National Park in Tanzania. American Journal of Environmental Protection, 4, 120-126. https://doi.org/10.11648/j.ajep.20150403.12

[33] Jaafar, M., Rasoolimanesh, S.M. and Ismail, S. (2015) Perceived Sociocultural Impacts of Tourism and Community Participation: A Case Study of Langkawi Island. Tourism and Hospitality Research, 17, 123-134.

[34] Greene, S. (2005) Including Young Mothers: Community-Based Participation and the Continuum of Active Citizenship. Community Development Journal, 42, 167-180. https://doi.org/10.1093/cdj/bsi096

[35] Torgerson, M. and Edwards, E.M. (2012) Demographic Determinants of Perceived Barriers to Community Involvement: Examining Rural/Urban Differences. Nonprofit and Voluntary Sector Quarterly, 42, 371-390. https://doi.org/10.1177/0899764012440181

[36] Gaboyan, M. (2010) Demographic Factors Affecting Citizen Participation in Armenia.

https://www.crrc.am/hosting/file/_static_content/fellows/CELoG\%20Fellowship/20 16/Margarita\%20Gaboyan.\%20Factors\%20of\%20participation.pdf

[37] Oladele, O.I. (2012) Socio-Economic Determinants of Use of Indigenous Fallow System for Enhancing Soil Fertility among Farmers in Oyo State of Nigeria. Life 
Science Journal, 9, 2424-2428.

[38] Harrill, R. (2004) Residents' Attitudes toward Tourism Development: A Literature Review with Implications for Tourism Planning. Journal of Planning Literature, 18, 251-266. https://doi.org/10.1177/0885412203260306

[39] John, P. (2009) Can Citizen Governance Redress the Representative Bias of Political Participation? Public Administration Review, 69, 494-503. https://doi.org/10.1111/j.1540-6210.2009.01995.x

[40] Joshi, A. and Houtzager, P. (2012) Widgets or Watchdogs? Conceptual Explorations in Social Accountability. Public Management Review, 14, 145-162. https://doi.org/10.1080/14719037.2012.657837

[41] Mugizi, F., Ayorekire, J. and Obua, J. (2017) Factors That Influence Local Community Participation in Tourism in Murchison Falls Conservation Area. Journal of Environmental Science and Engineering A, 6, 209-223.

[42] Speer, P.W., Peterson, N.A., Armstead, T.L. and Allen, C.T. (2013) The Influence of Participation, Gender and Organizational Sense of Community on Psychological Empowerment: The Moderating Effects of Income. American Journal of Community Psychology, 51, 103-113. https://doi.org/10.1007/s10464-012-9547-1

[43] Shamiyulla, N. and Ramu, J. (2010) Participatory Irrigation Management (PIM) in the Context of Future of Irrigation in India, Asian. Journal of Development Matters, 4, 18-27.

[44] Ganesh, P.S. and Surendra, B.T. (2005) Farmers' Perception of Participation and Institutional Effectiveness in the Management of Mid-Hill Watershed in Nepal. Environment and Development Economics, 10, 665-687.

[45] Saidu, M.B., Samah, A.A., Redzuan, M. and Ahmad, N. (2014) Relationship between Socio-Economic Factors and Participation in Decision Making in Microfinance Scheme among Rural Farmers in Kano, Nigeria. Life Science Journal, 11, 342-347.

[46] Jansky, L. and Juha, I.U. (2006) Enhancing Participation in Water Resources Management. Conventional Approaches and Information Technology. Environmental Conservation, 33, 274.

[47] Odege, D.W. (2014) Factors Influencing Community Participation in Cultural Tourism at Kit Mikayi in Kisumu County, Kenya. Unpublished Masters Dissertation, University of Nairobi, Nairobi.

[48] Yeboah, T. (2013) Assessing Community Participation in Selected Ecotourism Projects in the Brong-Ahafo Region, Ghana. Journal of Ecology and the Natural Environment, 5, 133-143. https://doi.org/10.5897/JENE2012.0351

[49] Brodie, E., Cowling, E. and Nissen, N. (2009) Understanding Participation: A Literature Review. National Council for Voluntary Organisations. 